International Journal of Forestry and Crop Improvement

\title{
Influence of poultry composts on growth and yield attributes of sunflower
}

\author{
M. Prasanthrajan, P. Doraisamy, M. Pandiyan and K.P. Sivakumar
}

\begin{abstract}
A field trial was conducted with twelve treatments to test the effectiveness of poultry - carbonaceous wastes compost on the soil properties, growth and yield attributes of sunflower (Var-CO1). Application of compost improved the soil fertility by adding humus and nutrients. Compost along with 100\% (60: 45: $\left.45 \mathrm{~kg} \mathrm{NPK} \mathrm{ha}^{-1}\right)$ and 75\% (45: 33: $\left.33 \mathrm{~kg} \mathrm{NPK} \mathrm{ha}^{-1}\right)$ recommended NPK increased the growth and yield of sunflower. Among the composts (Poultry droppings and coir pith, poultry droppings and paddy straw, poultry droppings and coir pith with rock phosphate), the coir pith, rock phosphate mixed poultry compost performed well. The coir pith and rock phosphate added poultry compost along with recommended levels of NPK recorded higher yield which was at par with the results of coir pith mixed poultry compost along with 75 per cent levels of recommended N, P and K. Compost application improved the crop yield, soil fertility status and saved 25 per cent of fertilizer.
\end{abstract}

KEY WORDS : Poultry waste, Compost, Sunflower yield, Soil properties

How to cite this Article : Prasanthrajan, M., Doraisamy, P., Pandiyan, M. and Sivakumar, K.P. (2014). Influence of poultry composts on growth and yield attributes of sunflower. Internat. J. Forestry \& Crop Improv., 5 (2) : 37-41.

Article Chronical : Received : 31.07.2014; Revised : 20.10.2014; Accepted : 06.11.2014

MEMBERS OF RESEARCH FORUM

Address of the Correspondence :

M. PRASANTHRAJAN, Agricultural Research Station, Virinjipuram, VELLORE (T.N.) INDIA

Email: prasanth_phd@yahoo.co.in

Address of the Coopted Authors :

P. DORAISAMY, M. PANDIYAN AND K.P. SIVAKUMAR, Department

of Environmental Science, Tamil Nadu Agricultural University, COIMBATORE (T. N.) INDIA 